\author{
Marek Nowacki \\ https:/ / orcid.org/0000-0002-6981-7698 \\ Wyższa Szkoła Bankowa w Poznaniu \\ Wydział Finansów i Bankowości, Instytut Społeczno-Ekonomiczny \\ marek.nowacki@wsb.poznan.pl
}

\title{
CHARAKTERYSTYCZNE ELEMENTY MAREK POLSKICH MIAST W RECENZJACH DOSTĘPNYCH ONLINE
}

\begin{abstract}
Abstrakt: Celem pracy jest zidentyfikowanie charakterystycznych elementów marek polskich miast oraz wskazanie podobieństw i różnic występujących pomiędzy nimi. Praca ma dać odpowiedź na następujące pytania badawcze: Które elementy w istotny sposób wpływają na odróżnianie marek badanych miast w recenzjach dostępnych online? Które z badanych miast są do siebie najbardziej zbliżone pod względem elementów marki, a które różnią się pod tym względem? Dane do analizy pobrano z serwisu TripAdvisor. Były to opinie dotyczące rejonów koncentracji ruchu turystycznego - starych rynków lub starych miast - pięciu polskich miast: Poznania, Wrocławia, Krakowa, Gdańska i Warszawy $(\mathrm{N}=5125)$. Przeprowadzone analizy pozwoliły zidentyfikować unikatowe elementy marek badanych miast i wskazać podobieństwa oraz różnice występujące pomiędzy markami.
\end{abstract}

Słowa kluczowe: kapitał marki, destynacje, TripAdvisor, Text Mining.

\section{WSTĘP}

Marka, według Kotlera (1994), to nazwa, termin, symbol, wzór lub ich kombinacja, stworzone w celu identyfikacji dóbr lub usług i wyróżnienia ich spośród konkurencji. Możliwości zastosowania koncepcji marki w odniesieniu do obszarów recepcji ruchu turystycznego (destynacji turystycznych) potwierdziło w swoich badaniach wielu autorów (Buhalis, 2000; Konecnik, Gartner, 2007; Woodside, Cruickhank, Dehuang, 2007). Branding jest techniką marketingową polegającą na budowaniu świadomości marki poprzez nadawanie produktom i usługom siły marki. Jego głównym celem jest wykreowanie różnic pomiędzy poszczególnymi produktami i usługami (Kotler, Bowen, Makens, Baloglu, 2017). Branding uważany jest obecnie za niezwykle istotny aspekt praktyki zarządzania obszarem recepcji turystycznej, ponieważ rosnące możliwości wyjazdów turystycznych oraz liczba dostępnych kierunków powodują zwiększoną substytucyjność i brak zróżnicowania pomiędzy kierunkami wyjazdów (Pike, 2005). Z kolei kapitał marki to według Aakera (2009) zbiór aktywów, takich jak: świadomość, lojalność konsumentów, postrzegana jakość i skojarzenia związane z marką, a także wartość dodana do oferowanych produktów lub usług. Ważnym zadaniem badawczym, w kontekście zarządzania obsza- obszarami recepcji turystycznej, jest zatem badanie percepcji i kapitału marek oraz ich oddziaływania na zachowania konsumentów usług turystycznych.

Kapitał marki można określać w dwojaki sposób. W pierwszym ujęciu za wskaźnik przyjmuje się wynik finansowy, który organizacja zawdzięcza marce. $W$ drugim sposobie kapitał marki ocenia się z perspektywy konsumentów (Boo, Busser, Baloglu, 2009). Jest to tzw. kapitał marki zorientowany na konsumenta lub oparty na konsumencie (ang. customer-based brand equity - CBBE). Keller (1993, s. 8) definiuje go jako „różnicujący efekt wiedzy o marce na reakcje konsumentów, w odpowiedzi na marketing marki". Jest on oparty na skojarzeniach i postawach użytkowników marki. Aaker (2009, s. 15-16) wymienia następujące wymiary kapitału marki: lojalność wobec marki, świadomość jej nazwy, postrzegana jakość, skojarzenia z marką i pozostałe aktywa, takie jak: patenty, znaki towarowe, kanały dystrybucji $\mathrm{i}$ inne. Pierwsze cztery z wymienionych wymiarów związane są z percepcją kapitału marki opartego na konsumencie. Florek (2014) wskazuje na dwa wymiary źródeł kapitału marki - percepcyjny (mierzony świadomością marki, skojarzeniami, wizerunkiem, postrzeganą jakością) oraz behawioralny (mierzony lojalnością wobec marki, chęcią zapłaty lub rekomendacją). 
Pojęcie kapitału marki w odniesieniu do miejsca (kraju), w polskiej literaturze określane jako kapitał marki terytorialnej, jako pierwszy sformułował Papadopoulos (2004, s. 43). Uważał on, ż są to „rzeczywiste i/lub postrzegane aktywa i pasywa, które kojarzone są z miejscem (krajem) i odróżniają je od innych".

$\mathrm{W}$ jednej z pierwszych prac empirycznych dotyczących kapitału marki terytorialnej Konecnik i Gartner (2007) zaproponowali model kapitału marki opartej na percepcji turystów. W wyniku badań ankietowych, przeprowadzonych wśród chorwackich i niemieckich turystów, autorzy dostrzegli istnienie czterech wymiarów kapitału marki Słowenii: świadomości, wizerun$\mathrm{ku}$, jakości i lojalności. Zidentyfikowali także liczne zależności zachodzące pomiędzy wymiarami marki oraz stwierdzili, że to wizerunek jest centralnym pojęciem w brandingu miejsc. Okazało się jednak, że gdy marka destynacji staje się znana konsumentom, wizerunek przenosi się na wymiary marki i jest przez nią niejako przysłaniany. Konecnik i Gartner (2007) zauważyli również, że poszczególne wymiary kapitału marki oddziałują na wymiary wizerunku (rys. 1). Na przykład świadomość marki najbardziej wpływa na wymiar kognitywny wizerunku, bez którego nie istnieje kapitał marki. Wymiary wizerunku i jakości marki najsilniej działają na wymiar afektywny wizerunku. Z kolei lojalność wobec marki wpływa na wymiar konatywny wizerunku. Tak więc zarówno wzajemne zależności pomiędzy wymiarami wizerunku, jak i skumulowana wartość komponentów marki tworzą w sumie kapitał marki destynacji.

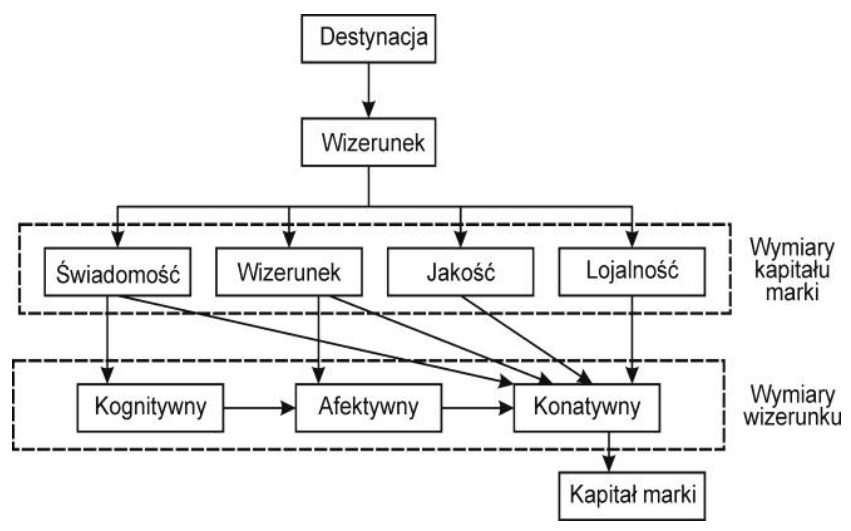

Rys. 1. Tworzenie się kapitału marki destynacji Źródło: Konecnik, Gartner (2007, s. 403); opracowanie własne

Inne, bardzo interesujące badania wśród turystów amerykańskich przeprowadzili Boo i in. (2009). Wykonali oni badania online gości Las Vegas i Atlantic City, jako kierunków turystyki hazardowej. Badacze skonstruowali i przetestowali specyficzne skale do pomiaru czterech wymiarów marki destynacji hazardowej. Stwierdzili, że możliwe jest badanie kapitału marki destynacji za pomocą modelu CBBE, jednak marki te powinny być oceniane poprzez porównanie $\mathrm{z}$ innymi konkurującymi destynacjami $\mathrm{w}$ tej samej kategorii. Badane $w$ ten sposób marki powinny być łatwo rozpoznawalne i popularne, a destynacje znane badanym osobom z autopsji. Badacze uznali, że przystępując do badania marki destynacji, każdorazowo powinno się skonstruować specyficzną skalę, uwzględniającą charakter porównywanych ze sobą obszarów.

Lucarelli (2012), po dokonaniu przeglądu literatury (217 artykułów angielskojęzycznych, opublikowanych w latach 1990-2009), zaproponował trójwymiarowy, interdyscyplinarny model analizy i oceny kapitału marki miasta, na który składają się: elementy marki miast, pomiar oddziaływania marek miast i wpływ brandingu na miasta. Do elementów marki miast Lucarelli zalicza: historię i dziedzictwo niematerialne, artefakty i planowanie przestrzenne (muzea, zabytki, dzielnice, centra), wydarzenia i różną aktywność, procesy i instytucje oraz grafiki i symbole (Lucarelli, 2012).

Interesujące badania nad kapitałem marki miasta zorientowanym na konsumenta wykonała także Florek (2014). W wyniku badań ankietowych przeprowadzonych wśród mieszkańców Poznania i Wrocławia autorka wyodrębniła cztery wymiary kapitału marki miasta: przywiązanie, percepcję, rekomendację i satysfakcję.

Kryteria wyboru obszarów, których porównanie marek gwarantowałoby trafność zewnętrzną pomiaru (external validity), sformułował na podstawie przeglądu literatury Leicht (2016). Są to:

- porównywalna powierzchnia obszaru, czyli np. miasto $\mathrm{z}$ miastem, region $\mathrm{z}$ regionem;

- kontekst przestrzenno-kulturowy oferujący co najmniej pewien stopień zróżnicowania, np. położenie $\mathrm{w}$ różnych miejscach $\mathrm{i} / \mathrm{lub}$ sferach kulturowych;

- porównywalny typ produktu, miejsca lub oferowanych usług.

\section{RECENZJE DOSTĘPNE ONLINE, BIG DATA I TEXT MINING}

Informacje przekazywane $\mathrm{z}$ ust do ust (word of mouth - WOM) od lat stanowią istotny czynnik w procesie kształtowania się wizerunku miejsc (Brown, Getz, 2005; Jalilvand, Shekarchizadeh, Samiei, 2011). Jednakże wraz z pojawieniem się mediów społecznościowych, Internetu $2.0^{1}$ i treści generowanych przez użytkowników (user generated content - UGC) zjawisko to zaczęło przyjmować zupełnie nowy charakter. Liczne internetowe fora podróżnicze i agregatory opinii, takie jak np.: TripAdvisor, Lonely Planet czy Ciao, 
dostarczają niezliczonych informacji, które w istotny sposób wpływają na decyzje konsumenckie ich użytkowników. Tę formę przekazywania informacji określa się mianem elektronicznej komunikacji nieformalnej (electronic word of mouth - eWOM) i uznaje się ją za najbardziej wpływowe źródło informacji (Jalilvand, 2016).

Cantallops i Salvi (2014) oraz Casalo, Flavian, Guinaliu i Ekinci (2015) stwierdzili, że spośród wszystkich źródeł informacji eWOM ma największy wpływ na konsumentów usług turystycznych, a wynika to głównie $\mathrm{z}$ powodu niematerialnego charakteru tych usług. Miliony opinii dostępnych stale online ${ }^{2}$ tworzą ogromny i zróżnicowany zbiór danych zwany Big Data, którego przetwarzanie za pomoca algorytmów komputerowych (Data Mining i Text Minig) daje możliwość zdobycia nowej, niedostępnej dotychczas wiedzy (Kuhzady, Ghasemi, 2019; Liu, Huangb, Bao, Chenc, 2019; Nowacki, 2019).

Text Minig odnosi się do procesu zdobywania wysokiej jakości informacji z danych tekstowych i zawiera szeroki zakres tematów oraz algorytmów służących do analizy tekstu, odnoszących się do różnych społeczności i obejmujących wyszukiwanie informacji, przetwarzanie języka naturalnego, eksplorację danych i uczenie maszynowe (Allahyari i in., 2017). Wraz z pojawieniem się e-handlu i zakupów online, zaczęła powstawać ogromna liczba recenzji produktów i opinii użytkowników, która wciąż rośnie. Analizując takie dane, można uzyskać ważne informacje i opinie na tematy, które mają zasadnicze znaczenie $\mathrm{w}$ reklamie i marketingu prowadzonym online (Allahyari i in., 2017).

\section{CEL PRACY I PYTANIA BADAWCZE}

Poszukiwanie elementów charakterystycznych marek obszarów recepcji turystycznej można przeprowadzić poprzez analizę recenzji dostępnych online na dwa sposoby: jakościowy i ilościowy. Badania jakościowe prowadziła m.in. Niezgoda (2017), identyfikując wśród opinii dostępnych $\mathrm{w}$ TripAdvisorze trzy wymiary wizerunków pałaców w Wersalu i Caserta. Greckie badaczki Kladou i Mavragani (2015) określiły wymiary wizerunku Istambułu, zaś Nowacki (2017) zidentyfikował cechy wizerunków światowych metropolii. Prowadzone były także badania ilościowe, takie jak np.: identyfikowanie doświadczeń kulturowych wśród osób zwiedzających atrakcje kulturowe Neapolu (Simeon, Buonincontri, Cinquegrani, Martone, 2017), unikatowych słów kojarzonych z Bałkanami (Smith i in., 2018) czy słów charakterystycznych dla Barcelony (Tamajón, Valiente, 2015). Interesujące badania przeprowadzili także Nakaima,
Marchiori i Cantoni (2019), identyfikując na podstawie analizy opinii zawartych $\mathrm{w}$ TripAdvisorze doświadczenia turystów odwiedzających dziesięć wysp, stanowiących popularne kierunki wyjazdów wakacyjnych.

W świetle powyższych ustaleń można stwierdzić, że $\mathrm{w}$ badaniach istnieje luka $\mathrm{w}$ zakresie identyfikacji charakterystycznych elementów marek obszarów recepcji turystycznej (por. Lucarelli, 2012), zwłaszcza metodą porównawczą, z wykorzystaniem zbioru danych Big Data i algorytmu Text Minig oraz zaawansowanych metod statystycznych. W związku z tym, celem niniejszych badań uczyniono zidentyfikowanie charakterystycznych elementów marek polskich miast oraz wskazanie podobieństw i różnic występujących pomiędzy nimi, formułując następujące pytania badawcze:

Pytanie badawcze 1: Jakie elementy marek $\mathrm{w}$ istotny sposób odróżniają od siebie badane miasta $\mathrm{w}$ recenzjach dostępnych online?

Pytanie badawcze 2: Które z badanych miast są do siebie najbardziej zbliżone pod względem zidentyfikowanych elementów marek, a które różnią się pomiędzy sobą?

\section{METODA}

Jako materiał badawczy wykorzystano recenzje dostępne w angielskojęzycznym portalu TripAvisor (https:// www.tripadvisor.co.uk). Wybrano kategorie wpisów dotyczących atrakcji turystycznych $w$ badanych miastach (Things to do in...): w centrum, na starówce, starym rynku, czyli $w$ głównych rejonach koncentracji ruchu turystycznego w mieście (por. Kladou, Mavragani, 2015). Na obszarach tych jest położonych wiele różnorodnych atrakcji turystycznych, takich jak: kościoły, ratusze, pomniki, fontanny, muzea, restauracje, hotele, sklepy z pamiątkami, punkty informacji turystycznej $i$ in.

Do badań wytypowano pięć najbardziej popularnych miast turystycznych w Polsce: Poznań, Wrocław, Warszawę, Gdańsk i Kraków. W Poznaniu i we Wrocławiu analizie poddano opinie dotyczące rynków Starego Miasta (Old Market Square), zaś w pozostałych miastach dzielnice - Stare Miasto (Old Town) (w TripAdvisorze dla Poznania nie ma kategorii Stare Miasto, zaś dla Wrocławia w tej kategorii było tylko 425 opinii - 16 lutego 2019 r.). Ponieważ najmniej opinii w porównywanych kategoriach (Starego Rynku / Starego Miasta) było w Poznaniu (1026), aby zachować proporcje, pobrano dla każdego miasta dokładnie 1025 opinii (tab. 1). Pozyskano je 15 lutego 2019 r. za pomocą aplikacji Web Scraper (2019). W sumie dla wszystkich miast pobrano 5125 opinii dostępnych online. 
Tab. 1. Zebrane dane według miejscowości i kategorii rejonu koncentracji ruchu turystycznego $(\mathrm{N}=5125)$

\begin{tabular}{|l|c|c|c|}
\hline \multicolumn{1}{|c|}{ Miasto } & Kategoria & Liczba & $\%$ \\
\hline Poznań & Stary Rynek & 1025 & 20 \\
\hline Wrocław & Stary Rynek & 1025 & 20 \\
\hline Warszawa & Stare Miasto & 1025 & 20 \\
\hline Gdańsk & Stare Miasto & 1025 & 20 \\
\hline Kraków & Stare Miasto & 1025 & 20 \\
\hline Suma & 5125 & 100 \\
\hline
\end{tabular}

Źródło: badania własne.
Uzyskane dane poddano analizie Data Mining / Text Mining w pakiecie statystycznym Statistica 11.0. Najpierw ustalono liczebność (częstość występowania) poszczególnych słów w komentarzach. W następnej kolejności wykonano jednoczynnikową analizę wariancji ANOVA, dzięki której stwierdzono, jakie słowa pozwalają na różnicowanie badanych miast. W ostatniej fazie obliczeń wykonano analizę korespondencji, za pomocą której zbadano zależności pomiędzy zmiennymi (miastami) a przypadkami (słowami). To pozwoliło zilustrować zależności na dwuwymiarowym wykresie słów-miast.

Tab. 2. Jednoczynnikowa analiza wariancji (ANOVA) występowania słów w opiniach dotyczących poszczególnych miast $(\mathrm{N}=105)$

\begin{tabular}{|c|c|c|c|c|c|c|c|c|}
\hline Słowo & $F$ & $p$ & Słowo & $F$ & $p$ & Słowo & $F$ & $p$ \\
\hline Also & 7,088 & 0,000 & Full & 5,126 & 0,000 & Pretty & 2,480 & 0,042 \\
\hline Amaze & 4,485 & 0,001 & Get & 6,770 & 0,000 & Price & 0,275 & 0,894 \\
\hline Architecture & 11,286 & 0,000 & Go & 1,342 & 0,252 & Pub & 16,524 & 0,000 \\
\hline Area & 15,086 & 0,000 & Good & 5,577 & 0,000 & Really & 2,545 & 0,038 \\
\hline Around & 3,364 & 0,009 & Great & 6,105 & 0,000 & Rebuilt & 58,471 & 0,000 \\
\hline Atmosphere & 4,610 & 0,001 & Hall & 68,695 & 0,000 & Recommend & 3,487 & 0,008 \\
\hline Back & 3,732 & 0,005 & Historic & 22,986 & 0,000 & Restaur & 29,616 & 0,000 \\
\hline Bar & 24,999 & 0,000 & History & 31,318 & 0,000 & See & 7,343 & 0,000 \\
\hline Beauty & 6,976 & 0,000 & Hour & 5,924 & 0,000 & Shop & 29,811 & 0,000 \\
\hline Best & 3,597 & 0,006 & House & 22,064 & 0,000 & Sit & 5,905 & 0,000 \\
\hline Build & 2,648 & 0,032 & Interest & 1,431 & 0,221 & Small & 8,097 & 0,000 \\
\hline Busy & 1,127 & 0,342 & Just & 4,325 & 0,002 & Spend & 1,921 & 0,104 \\
\hline Cafe & 2,140 & 0,073 & Like & 0,931 & 0,444 & Square & 342,014 & 0,000 \\
\hline Can & 2,058 & 0,084 & Little & 1,230 & 0,445 & Stay & 2,792 & 0,025 \\
\hline Charm & 1,961 & 0,098 & Local & 0,876 & 0,296 & Still & 5,774 & 0,000 \\
\hline Christmas & 24,863 & 0,000 & Look & 2,438 & 0,477 & Street & 43,598 & 0,000 \\
\hline Church & 28,323 & 0,000 & Lot & 4,847 & 0,045 & Stroll & 2,548 & 0,037 \\
\hline City & 5,533 & 0,000 & Love & 2,938 & 0,001 & Surround & 9,438 & 0,000 \\
\hline Clean & 7,796 & 0,000 & Main & 14,745 & 0,019 & Take & 6,572 & 0,000 \\
\hline Coffee & 0,441 & 0,779 & Make & 0,360 & 0,000 & Time & 1,070 & 0,370 \\
\hline Color & 18,147 & 0,000 & Many & 3,772 & 0,837 & Tour & 20,345 & 0,000 \\
\hline Colour & 21,513 & 0,000 & Market & 118,381 & 0,005 & Tourist & 0,538 & 0,708 \\
\hline Come & 3,480 & 0,008 & Much & 6,826 & 0,000 & Town & 121,924 & 0,000 \\
\hline Day & 2,794 & 0,025 & Museum & 10,610 & 0,000 & Visit & 4,310 & 0,002 \\
\hline Definite & 0,296 & 0,881 & Must & 3,959 & 0,000 & Walk & 34,767 & 0,000 \\
\hline Differ & 1,147 & 0,332 & Nice & 10,382 & 0,003 & War & 58,569 & 0,000 \\
\hline Drink & 5,785 & 0,000 & Night & 6,928 & 0,000 & Watch & 14,786 & 0,000 \\
\hline Eat & 1,823 & 0,122 & Old & 115,270 & 0,000 & Well & 0,487 & 0,746 \\
\hline Enjoy & 2,054 & 0,084 & One & 8,581 & 0,000 & Will & 2,526 & 0,039 \\
\hline Even & 1,885 & 0,110 & Part & 15,873 & 0,000 & Wonder & 1,599 & 0,172 \\
\hline Every & 2,990 & 0,018 & People & 1,461 & 0,000 & World & 7,502 & 0,000 \\
\hline Feel & 4,145 & 0,002 & Place & 6,490 & 0,211 & Worth & 0,998 & 0,407 \\
\hline Find & 2,767 & 0,026 & Plenty & 2,365 & 0,000 & Would & 2,149 & 0,072 \\
\hline Food & 1,533 & 0,190 & Poland & 6,141 & 0,051 & & & \\
\hline Friend & 2,208 & 0,066 & Polish & 4,229 & 0,000 & & & \\
\hline
\end{tabular}

Uwaga: liczby złożone pismem wytłuszczonym wskazują na słowa w istotny sposób różnicujące badane miasta.

Objaśnienia: $p$ - poziom ufności, $F$ - wartości statystyki f-Fishera.

Źródło: badania własne. 


\section{WYNIKI BADAŃ}

Na wstępie policzono słowa najczęściej występujące we wszystkich komentarzach. Wykluczono zbiór wyrazów zawarty w zbiorze EnglishStopList.txt w pakiecie Statistica, czyli takie słowa, jak np. " $a$ ", "the" itp. Następnie wykonano procedurę lematyzacji (stemmingu), polegającą na sprowadzeniu form fleksyjnych wyrazów do postaci słownikowej. Połączono więc w jedną kategorię różne formy gramatyczne tych samych słów, np.: "travelling", "traveled", "travel" itp. W wyniku tej procedury uzyskano listę 105 unikatowych słów (tab. 2). Następnie wykonano analizę wariancji ANOVA, której celem było znalezienie różnic pomiędzy średnimi liczbami wystąpień danego słowa w opiniach dotyczących poszczególnych miast. Poszukiwano wyrazów, których liczebność występowania w istotny sposób różnicuje pomiędzy sobą zbiory opinii dotyczących badanych miast. Okazało się, że 76 ze 105 słów w istotny sposób, na poziomie ufności $p<0,05$, różnicuje badane zbiory opinii (tab. 2).

Wykonany w ANOVA test $F$, wskazuje jedynie na istotność różnic pomiędzy wybranymi dowolnie z pięciu zbiorów opinii dotyczących każdego z miast. Aby stwierdzić, czy dwa zbiory opinii dla dwóch konkretnych miast $\mathrm{w}$ istotny sposób różnią się, dla każdego

Tab. 3. Wyłonione w wyniku analizy ANOVA unikatowe słowa, charakterystyczne dla każdego z badanych miast $(\mathrm{N}=74)$

\begin{tabular}{|c|c|c|c|c|c|c|c|c|c|}
\hline \multicolumn{2}{|c|}{ Poznań } & \multicolumn{2}{|c|}{ Wrocław } & \multicolumn{2}{|c|}{ Warszawa } & \multicolumn{2}{|c|}{ Gdańsk } & \multicolumn{2}{|c|}{ Kraków } \\
\hline słowo & liczba & słowo & liczba & słowo & liczba & słowo & liczba & słowo & liczba \\
\hline Also & 99 & Atmosphere & 105 & Area & 152 & Amaze & 98 & Amaze & 90 \\
\hline Bar & 244 & Beauty & 376 & Back & 45 & Architecture & 165 & Area & 146 \\
\hline Build & 273 & Best & 59 & Feel & 53 & Build & 272 & Around & 272 \\
\hline Color & 76 & Christmas & 133 & Hour & 55 & Museum & 63 & Back & 47 \\
\hline Colour & 74 & Drink & 98 & Nice & 231 & Small & 74 & Best & 53 \\
\hline Come & 48 & Find & 60 & Old & 597 & Stay & 52 & Church & 152 \\
\hline Day & 128 & Full & 89 & Part & 79 & Street & 257 & City & 298 \\
\hline Drink & 93 & Great & 282 & Polish & 63 & Visit & 305 & Clean & 70 \\
\hline Good & 169 & Market & 299 & Rebuilt & 117 & & & Come & 40 \\
\hline Hall & 142 & Night & 75 & Small & 73 & & & Day & 126 \\
\hline House & 106 & One & 147 & Still & 57 & & & Every & 78 \\
\hline Market & 327 & People & 131 & Town & 647 & & & Full & 93 \\
\hline Museum & 67 & Pretty & 44 & War & 129 & & & Get & 91 \\
\hline Must & 93 & Restaur & 433 & World & 72 & & & Historic & 155 \\
\hline Nice & 281 & & & & & & & History & 170 \\
\hline Night & 89 & & & & & & & Interest & 87 \\
\hline People & 130 & & & & & & & Just & 150 \\
\hline Polish & 66 & & & & & & & Lot & 326 \\
\hline Pretty & 43 & & & & & & & Love & 249 \\
\hline$P u b$ & 63 & & & & & & & Main & 132 \\
\hline Restaur & 486 & & & & & & & Stay & 52 \\
\hline Sit & 54 & & & & & & & Much & 105 \\
\hline Square & 741 & & & & & & & Plenty & 107 \\
\hline Surround & 56 & & & & & & & Recommend & 71 \\
\hline Watch & 89 & & & & & & & See & 222 \\
\hline & & & & & & & & Shop & 338 \\
\hline & & & & & & & & Stay & 56 \\
\hline & & & & & & & & Street & 212 \\
\hline & & & & & & & & Stroll & 51 \\
\hline & & & & & & & & Take & 117 \\
\hline & & & & & & & & Tour & 138 \\
\hline & & & & & & & & Visit & 257 \\
\hline & & & & & & & & Walk & 356 \\
\hline & & & & & & & & Will & 75 \\
\hline & & & & & & & & Would & 60 \\
\hline
\end{tabular}

Źródło: badania własne. 
przypadku (słowa) wyłonionego w analizie ANOVA wykonano dodatkowo konserwatywny test post hoc Scheffégo (Kenneth, Bordens, Abbott, 2008). Analiza ta przyniosła 75 unikatowych dla badanych miast słów (tab. 3): najwięcej dla Krakowa (35), kolejno dla Poznania (25), Wrocławia oraz Warszawy (po 14) i Gdańska (8) ${ }^{3}$. Wybierano tylko te słowa, które istotnie wyróżniały jedno lub ewentualnie dwa miasta (postąpiono tak zaledwie w kilku przypadkach) - np. liczebność słowa "restaur" dla Poznania i Wrocławia wynosiła odpowiednio 486 i 433 i wyniki te były w istotny sposób większe niż dla Warszawy (273), Gdańska (352) i Krakowa (348).
Jak wynika z tab. 3, wiele spośród zidentyfikowanych wyrazów było mało charakterystycznych i niewiele mówiło o elementach marki danego miasta. Należały do nich takie słowa, jak np.: "also", "feel" czy "find". Aby w późniejszej analizie nie przesłaniały obrazu badanych miast, zdecydowano się je usunąć. Po przeprowadzeniu tej procedury do dalszych rozważań pozostały 42 słowa.

Dla takiego zbioru danych zastosowano następnie metodę analizy korespondencji (odpowiedniości) (Hill, 1974). Jest to opisowa i eksploracyjna technika, dostarczająca informacji o strukturze powiązań pomiędzy kolumnami (zmiennymi) i wierszami (przypadkami)

Tab. 4. Wyniki analizy korespondencji dla 42 przypadków (słów) i 5 zmiennych (liczebność słów wyłonionych w poszczególnych miastach)

\begin{tabular}{|c|c|c|c|c|c|}
\hline Wymiary & $\begin{array}{c}\text { Wartość } \\
\text { osobliwa }\end{array}$ & $\begin{array}{c}\text { Wartość } \\
\text { własna }\end{array}$ & $\begin{array}{c}\text { \% wyjaśnionej } \\
\text { wariancji }\end{array}$ & $\begin{array}{c}\text { \% skumulowanej } \\
\text { wyjaśnionej wariancji }\end{array}$ & Test chi $^{2}$ \\
\hline 1 & 0,337 & 0,114 & 78,28 & 78,28 & $3545,063^{\mathrm{a}}$ \\
\hline 2 & 0,120 & 0,014 & 9,95 & 88,24 & $450,915^{\mathrm{a}}$ \\
\hline 3 & 0,101 & 0,010 & 6,96 & 95,20 & 315,429 \\
\hline 4 & 0,084 & 0,007 & 4,79 & 100,00 & 217,308 \\
\hline
\end{tabular}

Uwaga: a - wartości istotne statystycznie na poziomie $p<0,05$.

Źródło: badania własne.

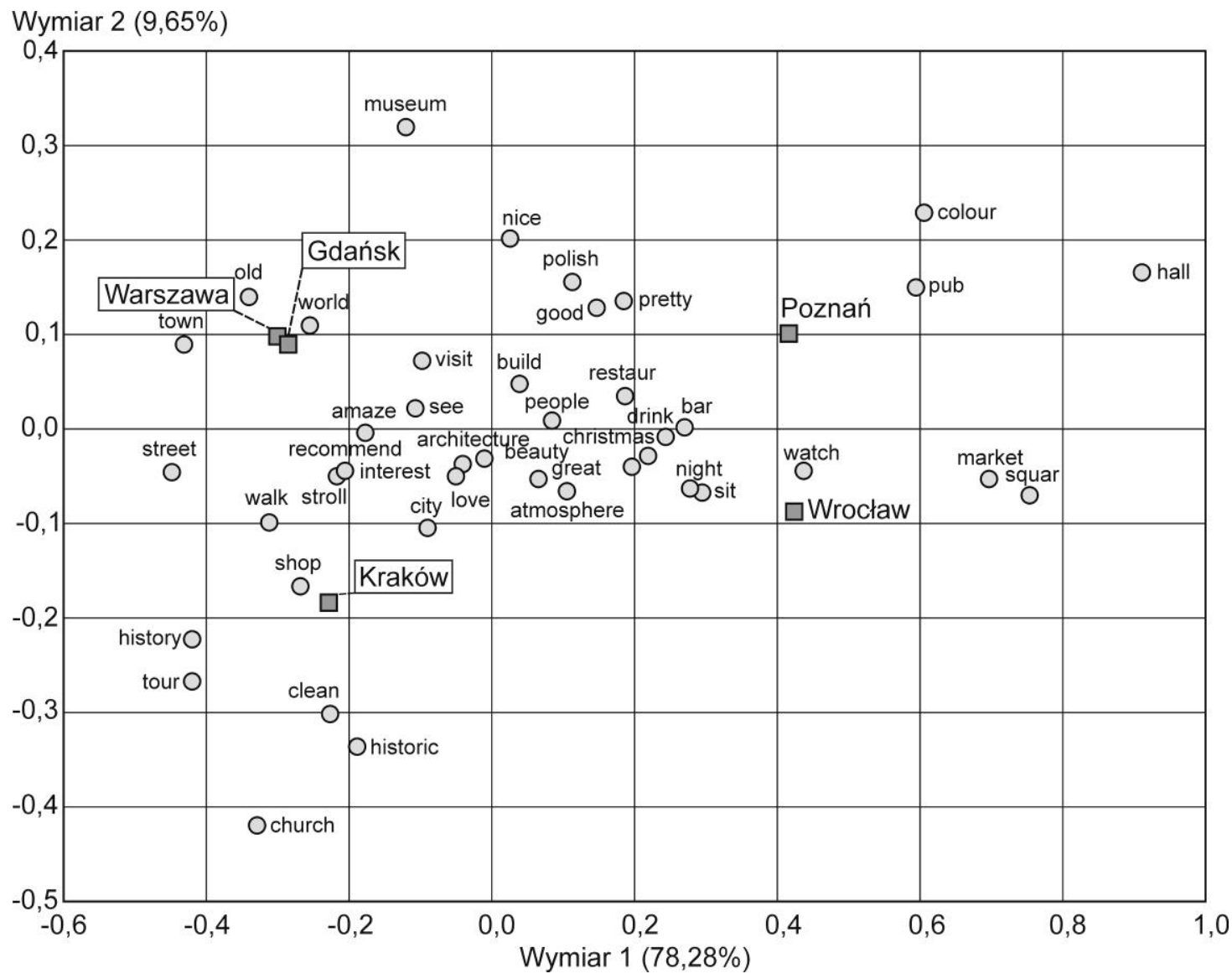

Rys. 2. Dwuwymiarowy wykres współrzędnych wierszy i kolumn dla 42 słów i pięciu miast Źródło: badania własne 
tabeli wielodzielczej (Stanisz, 2007). Dostarcza ona podobnych wyników jak analiza czynnikowa, lecz dla danych jakościowych.

Przed rozpoczęciem analizy korespondencji wykonano test $\chi^{2}$ Pearsona (dla poziomu ufności 95\%) dla tablicy danych: 42 przypadki (liczebności słów) x 5 zmiennych (liczebności słów $\mathrm{w}$ poszczególnych miastach): $\chi^{2}=4528,71, d f=164, p<0,0001$.

Test wykazał, że istnieje statystyczna zależność pomiędzy badanymi przypadkami a zmiennymi na poziomie istotności $p<0,0001$. Następnym krokiem było wykonanie analizy korespondencji, w efekcie czego uzyskano cztery wymiary, z których dwa pierwsze były istotne statystycznie. Pierwszy wymiar wyjaśnił aż 78,3\% wariancji zmiennych i wraz z drugim wymiarem łącznie wyjaśnił niemal $90 \%$ wariancji badanych zmiennych $(88,24 \%)$, co uznano za bardzo dobry wynik (tab. 4) (por. Stanisz, 2007).

Uzyskane wyniki przedstawiono $\mathrm{w}$ formie dwuwymiarowego wykresu (rys. 2), na którym kwadraty reprezentują badane miasta, zaś okręgi - wyłonione słowa. Na wykresie widać, że Kraków znalazł się w znacznej odległości od pozostałych miast. Słowami, które najbardziej odróżniają to miasto od pozostałych, są: shop (sklepy, zakupy), walk (spacery), clean (czysty), history tour (wycieczki historyczne), church (kościół). Kolejne dwa miasta, które znalazły się niemal w tym samym punkcie na wykresie, to Warszawa i Gdańsk, co oznacza, że w komentarzach charakteryzują je te same słowa: old town (Stare Miasto), world (świat) czy museum (muzeum). Ostatnie dwa miasta, także położone stosunkowo blisko siebie, to Poznań i Wrocław. Charakterystycznymi słowami są dla nich: drink bar, Christmas atmosphere (atmosfera świąt Bożego Narodzenia), market squar (rynek), hall (town hall - ratusz), restaur (restauracje), pretty good Polish (całkiem dobry polski), night, sit (noc, siedzieć).

\section{DYSKUSJA I WNIOSKI}

Celem przedstawionych badań było zidentyfikowanie charakterystycznych elementów marek polskich miast oraz wskazanie podobieństw i różnic występujących pomiędzy nimi. Cel ten zrealizowano, wykonując analizę Text Mining, ANOVA i analizę korespondencji, na bardzo dużej liczbie danych - 5125 opinii dostępnych w serwisie TripAdvisor.

Przeprowadzone badania pozwoliły zidentyfikować specyficzne słowa - elementy marki, którymi różnią się badane miasta (a konkretnie rejony starych rynków / Starych Miast). Elementy te mogą być wykorzystane do kreowania przekazów marketingowych, tworzenia treści witryn internetowych, kształtowania produktów turystycznych, a nawet do podejmowania prób budowania lub modyfikowania istniejących marek terytorialnych i wizerunków destynacji turystycznych.

Najwięcej specyficznych słów - elementów marki - zidentyfikowano dla Krakowa i Poznania. W świetle wykonanych analiz Kraków może kojarzyć się z wycieczkami historycznymi, spacerami po ulicach czystego miasta, ale także z miastem dającym możliwości zrobienia interesujących zakupów. Z Poznaniem łączą się stwierdzenia: "kolorowe miasto pełne pubów", "piękny ratusz", „świetne bary, puby i restauracje”, a także „ciekawe życie nocne".

Z powyższych badań wynika, że Poznań i Wrocław, a także Warszawa i Gdańsk mogą stać się celem dalszych badań porównawczych, z wykorzystaniem CBBE, gdyż spełniają wymienione wcześniej warunki, wskazane przez Leichta (2016). W analizach tych należałoby wykorzystać zidentyfikowane $\mathrm{w}$ niniejszym artykule unikatowe elementy marek wybranych miast.

Ograniczeniem przedstawionych badań jest wykorzystana w analizie pojedyncza kategoria starego rynku lub starówki. W dalszych studiach warto poszerzyć analizę o pozostałe atrakcje znajdujące się $\mathrm{w}$ miastach (Things to do in...), a także restauracje i hotele, dzięki czemu analizowane elementy marki miasta, a co za tym idzie model kapitału miasta stanie się pełniejszy. Warto także zidentyfikować formy aktywności i doświadczenia turystów charakterystyczne dla badanych miast, które wraz z wyżej wymienionymi charakterystycznymi elementami, mogłyby posłużyć do kształtowania produktów turystycznych, strategii marketingowych miast i kreowania kapitału marek miast.

\section{PRZYPISY}

${ }^{1}$ Internet (Web 2.0) - określenie serwisów internetowych, w których działaniu podstawową rolę odgrywa treść generowana przez użytkowników danego serwisu (Wikipedia).

${ }^{2}$ Na przykład TripAdvisor - największa na świecie witryna turystyczna - zawiera $702 \mathrm{mln}$ recenzji i opinii dotyczących $8 \mathrm{mln}$ miejsc noclegowych, linii lotniczych, atrakcji turystycznych i restauracji w 49 krajach. Co miesiąc $z$ informacji w nim zawartych korzysta $490 \mathrm{mln}$ unikatowych użytkowników (TripAdvisor, 2019).

${ }^{3}$ Suma słów jest większa niż 75, gdyż niektóre wyrazy uznano za charakterystyczne dla kilku miast.

\section{BIBLIOGRAFIA}

Aaker, D.A. (2009). Managing brand equity. Capitalizing on the value of a brand name. New York: The Free Press.

Allahyari, M., Pouriyeh, S., Assefi, M., Safaei, S., Trippe, E.D., Gutirrez, J.B., Kochut, K. (2017). A brief survey of Text Mining: 
classification, clustering and extraction techniques. Halifax: ArXiv e-prints, KDD Bigdas.

Boo, S., Busser, J., Baloglu, S. (2009). A model of customer-based brand equity and its application to multiple destinations. Tourism Management, 30, 219-231.

Brown, G., Getz, D. (2005). Linking wine preferences to the choice of wine tourism destinations. Journal of Travel Research, 43 (3), 266-276.

Buhalis, D. (2000). Marketing the competitive destination of the future. Tourism Management, 21 (1), 97-116.

Cantallops, A.S., Salvi, F. (2014). New consumer behavior: A review of research on eWOM and hotels. International Journal of Hospitality Management, 36, 41-51.

Casalo, L.V., Flavian, C., Guinaliu, M., Ekinci, Y. (2015). Do online hotel rating schemes influence booking behaviors? International Journal of Hospitality Management, 49, 28-36.

Florek, M. (2014). Kapitat marki miasta zorientowany na konsumenta. Źródła i pomiar. Poznań: Wydawnictwo Uniwersytetu Ekonomicznego w Poznaniu.

Hill, M.O. (1974). Correspondence analysis: A neglected multivariate method. Journal of the Royal Statistical Society. Series C (Applied Statistics), 23 (3), 340-354.

Jalilvand, M.R., Shekarchizadeh, S.S., Samiei, N. (2011). Electronic word-of-mouth: Challenges and opportunities. Procedia Computer Science, 3, 42-46.

Jalilvand, M.R. (2016). Word-of-mouth vs. mass media: Their contributions to destination image formation. Anatolia, 28 (2) 151-162.

Keller, K.L. (1993). Conceptualizing, measuring and managing customer-based brand equity. Journal of Marketing, 57 (1), $1-22$

Kenneth, S., Bordens, K.S., Abbott, B.B. (2008). Research design and methods. A process approach. Wyd. 7. New York: McGrawHill.

Kladou, S., Mavragani, E. (2015). Assessing destination image: An online marketing approach and the case of TripAdvisor. Journal of Destination Marketing \& Management, 4 (3), 187-193.

Konecnik, M., Gartner, W. (2007). Customer-based brand equity for a destination. Annals of Tourism Research, 34 (2), 400-421.

Kotler, P. (1994). Marketing. Analiza, planowanie, wdrażanie i kontrola. Warszawa: Gebethner \& Ska.

Kotler, P.T., Bowen, J.T., Makens, J., Baloglu, S. (2017). Marketing for hospitality and tourism (7 $7^{\text {th }}$ Edition, Global Edition). Essex: Pearson.

Kuhzady, S., Ghasemi, V. (2019). Factors influencing customers' satisfaction and dissatisfaction with hotels: A Text-Mining approach. Tourism Analysis, 24 (1), 69-79.

Leicht, T. (2016). Establishing external validity for consumerbased place brand equity scales: Mission impossible or a matter of approach? W: T.C. Melewar, K. Dinnie, C. Fona, C. Dennis (red.). Conference proceedings of inaugural conference of the international place branding association (s. 248-256). London: Middlesex University.
Liu, Y., Huangb, K., Bao, J., Chenc, K. (2019). Listen to the voices from home: An analysis of Chinese tourists' sentiments regarding Australian destinations. Tourism Management, 71, 337-347.

Lucarelli, A. (2012). Unravelling the complexity of "city brand equity": A three-dimensional framework. Journal of Place Management and Development, 5 (3), 231-252.

Nakaima, K., Marchiori, E., Cantoni, L. (2019). Identification of competing destination brand: The case of Okinawa island. W: J. Personen, J. Neidhardt (red.). Information and communication technologies in tourism (s. 172-183). Cham: Springer.

Niezgoda, A. (2017). Rola doświadczeń i relacji z podróży w kształtowaniu wizerunku miejsca. Marketing $i$ Zarzadzanie, 1 (47), 221-228.

Nowacki, M. (2017). Atrakcje turystyczne światowych metropolii w opinii użytkowników TripAdvisora. Studia Periegetica, 3 (19), 23-41.

Nowacki, M. (2019). World cities' image in TripAdvisor users' reviews. e-Review of Tourism Research (eRTR), 16 (2/3), 146-155.

Papadopoulos, N. (2004). Place branding: Evolution, meaning and implications. Place Branding, 1 (1), 36-49.

Pike, S. (2005), Tourism destination branding complexity. Journal of Product $\mathcal{E}$ Brand Management, 14 (4), 258-259.

Simeon, M.I., Buonincontri, P., Cinquegrani, F., Martone, A. (2017). Exploring tourists' cultural experiences in Naples through online reviews. Journal of Hospitality and Tourism Technology, 8 (2), 220-238.

Smith, M., Sulyok, J., Jancsik, A., Puczkó, L., Kiss, K., Sziva, I., Papp-Váry, Á.F., Michalkó, G. (2018). Nomen est omen - tourist image of the Balkans. Hungarian Geographical Bulletin, 67 (2), 173-188.

Stanisz, A. (2007). Przystępny kurs statystyki z zastosowaniem STATISTICA PL na przykładach z medycyny. Tom 3: Analizy wielowymiarowe. Kraków: StatSoft.

Tamajón, L.G., Valiente, G.C. (2015). Barcelona seen through the eyes of TripAdvisor: Actors, typologies and components of destination image in social media platforms. Current Issues in Tourism, 20 (1), 33-37.

TripAvisor. Pobrano z: https:/ / tripadvisor.mediaroom.com/ukabout-us (18.02.2019).

TripAvisor. Media Centre. Pobrano z: https:/ /tripadvisor.co. ukabout-us (15.01.2019).

Web Scraper. Pobrano z: https:/ / www.webscraper.io/ (17.01.2019).

Wikipedia. Pobrano z: https://pl.wikipedia.org/wiki/Web_2.0) (18.02.2019).

Woodside, A.G., Cruickshank, B.F., Dehuang, N. (2007). Stories visitors tell about Italian cities as destination icons. Tourism Management, 28, 162-174.

Artykuł wpłynął:

12 marca $2019 \mathrm{r}$.

Zaakceptowano do druku: 6 maja $2019 \mathrm{r}$ 